\title{
On the origin of the deep CFC maximum in the eastern Weddell Sea - numerical model results
}

\author{
Michael P. Schodlok, Christian B. Rodehacke ${ }^{1}$, Hartmut H. Hellmer, Aike \\ Beckmann \\ Alfred Wegener Institute for Polar- and Marine Research, Bremerhaven, Germany
}

\begin{abstract}
CFC tracer observations indicate that Prydz Bay in the Indian sector of the Southern Ocean is a region of deep and bottom water formation. Results of a circumpolar ocean circulation model which includes CFC, an age tracer, and numerical floats indicate Prydz Bay as being a convection site which contributes to the reservoir of freshly ventilated waters in the Weddell Sea. In contrast to the newly formed Weddell Sea Bottom Water, captured near bottom, water masses of Prydz Bay origin spread on horizons which pass the ridges confining the Weddell Sea, therefore, contributing directly to the ventilation of the global abyss.
\end{abstract}

\section{Introduction}

The Weddell Sea is traditionally regarded as one of the main locations for deep and bottom water formation around Antarctica [Gill, 1973]. Weddell Sea Deep Water (WSDW), a mixture of Warm Deep Water (WDW) and Weddell Sea Bottom Water (WSBW), spreads from the Weddell Sea into the world ocean where it is known as Antarctic Bottom Water (AABW).

The dominant dynamical feature of the Weddell Sea is the cyclonic circulation of the Weddell Gyre consisting of two subgyres [Beckmann et al., 1999]. Waters ventilated in the Weddell Sea spread towards the north with the deep western boundary current of the Weddell Gyre hugging the eastern continental slope of the Antarctic Peninsula. The South Scotia Ridge effectivly blocks its advance farther north; only small volumes of some WSDW escape into the Scotia Sea through deep $(\sim 3000 \mathrm{~m})$ passages [Locarnini et al., 1993]. Thus the remaining newly formed water flows to the east with the northern branch of the Weddell Gyre.

Transient tracers are a suitable method of detecting recently ventilated water masses [Bullister and Weiss, 1988] which carry high chlorofluorocarbon (CFC) concentrations. The injection of CFCs into deeper layers occurs vertically by convection and subduction followed by a lateral redistribution through advection and mixing.

Tracer observations at the Greenwich Meridian ex- 
hibit two deep cores of CFC maximum. The northern maximum located at the southern flank of the Mid Atlantic Ridge [Haine et al., 1998] is usually associated with deep/bottom water formed in the Weddell Sea spreading eastward with a bottom intensified current. The origin of the southern maximum located at the Antarctic continental slope is subject to speculation. Dickson [1994] suggested a recirculation of deep and bottom water to the west of the Kerguelen Plateau, hence this could be regarded as a contributing source for the southern core at the Prime Meridian [Archambeau et al., 1998]. However, the southern core being similar in CFC concentration [Klatt et al., 2001] cannot be replenished entirely by recirculating Weddell Gyre waters.

Since other locations along the Antarctic periphery have been identified as additional deep and bottom water sources [Jacobs and Georgi, 1977], we attempt to answer in this study the following questions:

i) Where is the origin of the southern CFC maximum core at the Greenwich Meridian?

ii) What are the pathways and travel times of its source waters?

iii) How much water does enter the Weddell Sea within this core and contributes to the renewal of Weddell Sea Deep Water (WSDW)?

\section{The Ocean Model}

The ocean model used belongs to a family of hydrostatic primitive equation ocean circulation models in the framework of BRIOS (Bremerhaven Regional Ice Ocean Simulations) [Beckmann et al., 1999]. The configuration of the model consists of a circumpolar model domain extending from $82^{\circ} \mathrm{S}$ to $50^{\circ} \mathrm{S}$ including shallow shelf areas as well as sub-ice shelf cavities. The horizontal grid focuses on the Wedell Sea sector, where the resolution is $1.5^{\circ}$ in zonal and $1.5^{\circ} \cos \Phi$ in meridional direction. Outside the Weddell sector, zonal grid spacing increases gradually to $6.75^{\circ}$.

A detailed description of the BRIOS model configuration and main model results has been provided by Beckmann et al. [1999].

\section{Tracer and float experiments}

To highlight the origin and spreading of dense Antarctic water masses we used several strategies: direct simulation of anthropogenic tracers (CFCs), the combined use of age and dye tracer simualtion and the computation of Lagrangian float trajectories. 
The CFC tracer runs were driven with a CFC climatology [Walker et al., 2000]. We used techniques for tracer input as described by England et al. [1994], e.g. boundary flux conditions and gas exchange dependency on sea ice and wind speed. For the CFC study, the model integration started in 1920 and was integrated for 77 years to reveal CFC characteristics in 1997.

Transports and transit times were determined with age tracers and numerical floats released off Amery Ice Shelf (see Figure 1). The age of a water parcel is defined as the time elapsed since the parcel under consideration left the region where its age is prescribed to be zero. In our case, for every grid box outside Prydz Bay the ageing with temporal evolution is calculated. Mixing processes are implemented in the same way as for temperature and salinity. With increasing time, values converge towards the mean spreading age as being a stable mixture between advected old water and local increase of age. In order to obtain the portion of the ventilated water mass, a dye tracer experiment was performed, i.e., every grid box was set to zero at the time of initialization except the area off Amery Ice Shelf, where the dye is prescribed as one.

\section{Results}

Figure 1 shows the simulated circumpolar CFC-11 concentration distribution in summer 1997 in the bottom layer of the model domain. Due to the temporal evolution of the input function, high concentrations depict recently ventilated water. There are several areas along Antarctica's periphery that reveal sites of high CFC concentration. The shelf areas off FilchnerRonne and Ross Ice Shelves, known to contribute to the deep and bottom water formation, contain the highest concentrations (maximum adjacent to Berkner Island). These areas are mainly broad continental shelves bounded by land which allow shelf water to gain salt from brine rejection during sea ice formation [Gill, 1973]. Water parcels containing high CFC-11 values thus mix into waters of the coastal current and follow the general gyre circulation.

A feature well-known from observations and reproduced by the model is a c-shaped region in the western Weddell Sea associated with the lowest concentrations of the entire model domain. This documents the model's ability to keep newly formed bottom water close to the continental slope without much lateral mixing with the interior of the basin and is consistent with the observations by, e.g., Fahrbach et al. [1995].

Newly ventilated water from the Ross Sea shelf interacts with the coastal current and also fills the Amund- 
sen abyssal plain via the Ross Gyre. In addition, to the west of the Ross Sea confined areas off Adélie and Wilkes Lands, and Prydz Bay contain newly formed water masses. This is consistent with the picture derived from recent observations [Rintoul, 1998]. Whilst high CFC contents at the sea floor (Figure 1) depict Prydz Bay as a ventilation site, this is also documented by a vertical temperature section of the upper $2000 \mathrm{~m}$ (Figure 2) showing a lense of low temperatures $\left(<-0.2^{\circ} \mathrm{C}\right)$ surrounded by warmer water. Winter Water is present in the upper $60 \mathrm{~m}$ of the water column below which isotherms rise towards the coast due to Circumpolar Deep Water (CDW) upwelling [Smith et al. 1984; Wong et al., 1998].

Another means of showing ventilation and spreading is the use of particles released off Amery Ice Shelf within the mixed layer (Figure 3), resulting in a cloud of particles spread over the entire water column. The ventilated water is advected with the coastal current towards the west where it becomes part of the southern branch of the Weddell Gyre. Travel times depend on the location within in the water column. Floats ventilated down to the depth of the CFC maximum core (lower than 3000 m) need $5.7 \pm 0.7$ years to reach the Greenwich Meridian. Floats higher in the water column, i.e., within the coastal current's high velocity core (depth range 2000 to $3000 \mathrm{~m}$ ) are faster by about a year.

The steady state dye tracer distribution near Greenwich Meridian (Figure 4) reveals the observed core structure across this transect. The highest concentrations are attached to the continental slope at a depth of about $3000 \mathrm{~m}$ corresponding to the deep core flowing westward into the Weddell Sea.

Mean transit times (MTT) of Prydz Bay Water (PBW) to the Prime Meridian are calculated using known PBW fraction and local ages Figure 5. MTT's for the southern core were calculated from year 15 to 25 of integration as the ratio of PBW to local water had reached an asymptotic value for these years.

The core has its highest fraction of PBW in $3250 \mathrm{~m}$ depth (dashed line). It takes about 5.9 years to reach the Greenwich Meridian. The velocity maximum at the continental slope is considerably higher in the water column revealing a lower travel time of 4.4 years at $2500 \mathrm{~m}$. $\mathrm{PBW}$ is concentrated in the core at the continental slope decreasing rapidly northward. In the model $2.5 \mathrm{~Sv}$ (the upper limit) with $0.2 \mathrm{~Sv}$ seasonal variability is transported across the Greenwich Meridian. This agrees well with observations Hoppema et al. [2000]. Transport values in summer are lowest increasing steadily towards winter. 


\section{Discussion and Conclusions}

Observations focused on deep and bottom water formation in the Indian sector of the Southern Ocean are sparse [Rintoul, 1998; Jacobs and Georgi, 1977; Wong et al., 1998]. Although coarse in resolution, our model results present a coherent picture of water masses being formed in and convected to great depth near Prydz Bay, finally advected along the continental slope towards the Weddell Sea as suggested by Meredith et al. [2000]. These findings are based on CFC model data, and age tracer and numerical float experiments.

The results do not reveal the deep double-core structure known from tracer sampling along the Greenwich Meridian (Fig. 4a), indicating that the observed core near the Mid-Atlantic Ridge has its origin in the southern Weddell Sea. This implies that the core near the continental slope, entering the Weddell Sea from the Prydz Bay area at a rate of $2.5 \mathrm{~Sv}$, additionally contributes to the reservoir of newly ventilated waters in the Weddell Sea. About 20\% of the PBW leaves the Weddell Sea eastward across the Prime Meridian while roughly $2 \mathrm{~Sv}$ escape through the gaps contributing to the ventilation of the World Ocean (Figure 3 ).

Hence, our results suggest that the southern core is not replenished by a recirculating northern core within the Weddell Gyre, but an independent feature from a ventilation site outside the Weddell Sea. This reduces the relative importance of the Weddell Sea as source for AABW.

Acknowledgments.

The ECMWF reanalysis data were received via the German Weather Service (DWD). The 'stand-alone' sea ice model run was performed by R. Timmermann. Thanks to IUP, oceanography group of University of Bremen for performing CFC measurements. C.B. Rodehacke was supported by the Deutsche Forschungsgemeinschaft (DFG) under grant RO 318/43-4.

\section{References}

Archambeau,A.S., A.C. Pierre, A. Poisson and B. Schauer, Distribution of oxygen and carbon stable isotopes and CFC-12 in the water masses of the Southern Ocean at $30^{\circ} \mathrm{E}$ from South Africa to Antarctica: results of the CIVA1 cruise, J. Mar. Syst., 1, 25-38, 1998.

Beckmann, A., H.H. Hellmer and R. Timmermann, A Numerical Model of the Weddell Sea: Large Scale Circulation and Water Mass Distribution , J. Geophys. Res., 104, 23375-23391, 1999.

Bullister, J.L. and R.F. Weiss, Determination of CCl3F and CCl2F2 in seawater and air, Deep Sea Res. Part I, 35, 839-853, 1988.

Dickson, B., The Spreading of Antarctic Bottom Water into 
the Indian Ocean - First Results of the UK ADOX Programme, WOCE Newsletter 16, 25-28, 1994.

England, M.H. and V. Garcon and J.-F. Minster, Chlorofluorocarbon uptake in a world ocean model 1. Sensitivity to the surface gas forcing, J. Geophys. Res., 99, 2521525233, 1994.

England, M.H., The Age of Water and Ventilation Timescales in a Global Ocean Model, J. Phys. Oceanogr., 25, 2756-2777, 1995.

Fahrbach, E., G.Rohardt, M. Schröder and V. Strass, Transport and structure of the Weddell Gyre, Ann. Geophys., 12, 840-855, 1994.

Fahrbach, E., G.Rohardt, N. Scheele, M. Schröder, V. Strass and A. Wisotzki, Formation and discharge of deep and bottom water in the northwestern Weddell Sea, J. Mar. Res., 53, 515-538, 1995.

Gill, A.E., Circulation and bottom water production in the Weddell Sea, Deep Sea Res. Part I, 20, 111-140, 1973.

Haine, T.W.N., A.J. Watson, M.I. Liddicoat and R.R. Dickson, The flow of Antarctic Bottom Water to the southwest Indian Ocean estimated using CFCs, J. Geophys. Res., 103, 27637-27653, 1998.

Hoppema, M., O. Klatt, W. Roether, E. Fahrbach, K.Bulsiewicz and G. Rohardt, Renewal of Weddell Sea Deep Water by lateral advection, Deep Sea Res. Part I, submitted, 2000.

Jacobs, S.S. and D.T. Georgi, Observations on the southwest Indian/Antarctic Ocean, A Voyage of Discovery, M. Angel (Ed.), 43-84, Pergamon, London, 1977.

Klatt, O., W. Roether, M. Hoppema, K. Bulsiewicz, U. Fleischmann, C.B. Rodehacke, E. Fahrbach, R.F. Weiss, and J.L. Bullister Repeated CFC sections at the Greenwich Meridian in the Weddell Sea, J. Geophys. Res., submitted, 2001.

Locarnini, R.A. and T. Whitworth III and W.D. Nowlin, Jr., The importance of the Scotia Sea on the outflow of Weddell Sea Deep Water, J. Mar. Syst., 51, 135-153, 1993.

Meredith M.P., R.A. Locarnini, K.A. Van Soy, A.J. Watson, K.J. Heywood, and B.A. King, On the soutces of Weddell Gyre Antarctic Bottom Water, J. Geophys. Res., 105, 1093-1104, 2000.

Rintoul, S., On the origin and influence of Adélie Land Bottom Water, Ocean, Ice, and Atmosphere: interactions at the Antarctic Continental Margin, Antarct. Res. Ser., S.S. Jacobs and R.F. Weiss (Eds.), 151-171, AGU, vol. 75, Washington, D.C., 1998.

Smith, N., Z. Dong, K. Kerry and S. Wright, Water masses and circulation in the region of Prydz Bay, Antarctica, Deep Sea Res. Part I, 31, 1121-1147, 1984.

Walker, S.J., R.F. Weiss and P.K. Salameh, Reconstructed histories of the annual mean atmospheric mole fractions for the halocarbons CFC-11, CFC-12, CFC-113, and carbon tetrachloride, J. Geophys. Res., 105, 14285-14296, 2000.

Wong, A.P.S., N.L. Bindoff and A. Forbes, Ocean-ice shelf interaction and possible bottom water formation in Prydz bay, Antarctica, Ocean, Ice, and Atmosphere: interactions at the Antarctic Continental Margin, Antarct. Res. Ser., S.S. Jacobs and R.F. Weiss (Eds.), 172-187, AGU, vol. 75, Washington, D.C., 1998. 
A. Beckmann, H.H. Hellmer and M.P. Schodlok, Alfred Wegener Institute for Polar and Marine Research, Bussestr. 24, D-27570 Bremerhaven, Germany. (email: beckmann@awi-bremerhaven.de; hhellmer@awibremerhaven.de; mschodlok@awi-bremerhaven.de)

C.B. Rodehacke, Institut für Umweltphysik, Abt. Ozeanographie, Universität Bremen, Postfach 330 440, D28334 Bremen, Germany. (e-mail: c04m@uni-bremen.de)

(Received October 13, 2000; revised April 2, 2001; accepted May 7, 2001.)

\footnotetext{
${ }^{1}$ at Institut für Umweltphysik, Universität Bremen, Bremen, Germany
} 
Figure 1. CFC distribution in the bottom layer of the BRIOS model domain after 77 years (Summer 1997). Bottom topography is contoured at $500 \mathrm{~m}$ intervals. The red box indicates the Prydz Bay area where floats and age tracers were released, the dashed line the section shown in Figure 4.

Figure 1. CFC distribution in the bottom layer of the BRIOS model domain after 77 years (Summer 1997). Bottom topography is contoured at $500 \mathrm{~m}$ intervals. The red box indicates the Prydz Bay area where floats and age tracers were released, the dashed line the section shown in Figure 4.

Figure 2. Mid-winter (beginning of September) temperature section of the upper $2000 \mathrm{~m}$ along $72^{\circ} \mathrm{E}$ of model year 20 .

Figure 2. Mid-winter (beginning of September) temperature section of the upper $2000 \mathrm{~m}$ along $72^{\circ} \mathrm{E}$ of model year 20 .

Figure 3. Modelled trajectories of particles released in the surface layer off Amery Ice Shelf. Particles were released in September at the time of deep convection. Travel times are symbolized. Islands are indicated by initials: SG - South Georgia, SSaI - South Sandwich Islands, SOI - South Orkney Islands and BI - Berkner Island. Major Ice Shelves are shaded.

Figure 3. Modelled trajectories of particles released in the surface layer off Amery Ice Shelf. Particles were released in September at the time of deep convection. Travel times are symbolized. Islands are indicated by initials: SG - South Georgia, SSaI - South Sandwich Islands, SOI - South Orkney Islands and BI - Berkner Island. Major Ice Shelves are shaded.

Figure 4. Comparison of CFC-11 concentration in $\mathrm{pmol} / \mathrm{kg}$, from Polarstern cruise ANT XV/4 along Prime Meridian in 1998 (left) with modelled dye tracer distribution along $0^{\circ} \mathrm{E}$, showing the water mass fraction originating in Prydz Bay after 30 years of integration (right). EIS - Ekstrøm Ice Shelf; MAR - Mid-Atlantic Ridge.

Figure 4. Comparison of CFC-11 concentration in pmol/kg, from Polarstern cruise ANT XV/4 along Prime Meridian in 1998 (left) with modelled dye tracer distribution along $0^{\circ} \mathrm{E}$, showing the water mass fraction originating in Prydz Bay after 30 years of integration (right). EIS - Ekstrøm Ice Shelf; MAR - Mid-Atlantic Ridge.

Figure 5. For selected depth intervals (circle: $2500 \mathrm{~m}$, diamond: $2750 \mathrm{~m}$, upward triangle: $3000 \mathrm{~m}$, downward triangle: $3250 \mathrm{~m}$ and square: $3500 \mathrm{~m}$ ), left: percentage of Prydz Bay Water in the southern core at Greenwich Meridian, right: transit time of water at Greenwich Meridian released at Prydz Bay. Legend depicts depth .

Figure 5. For selected depth intervals (circle: $2500 \mathrm{~m}$, diamond: $2750 \mathrm{~m}$, upward triangle: $3000 \mathrm{~m}$, downward triangle: $3250 \mathrm{~m}$ and square: $3500 \mathrm{~m}$ ), left: percentage of Prydz Bay Water in the southern core at Greenwich Meridian, right: transit time of water at Greenwich Meridian released at Prydz Bay. Legend depicts depth . 
Figure 1

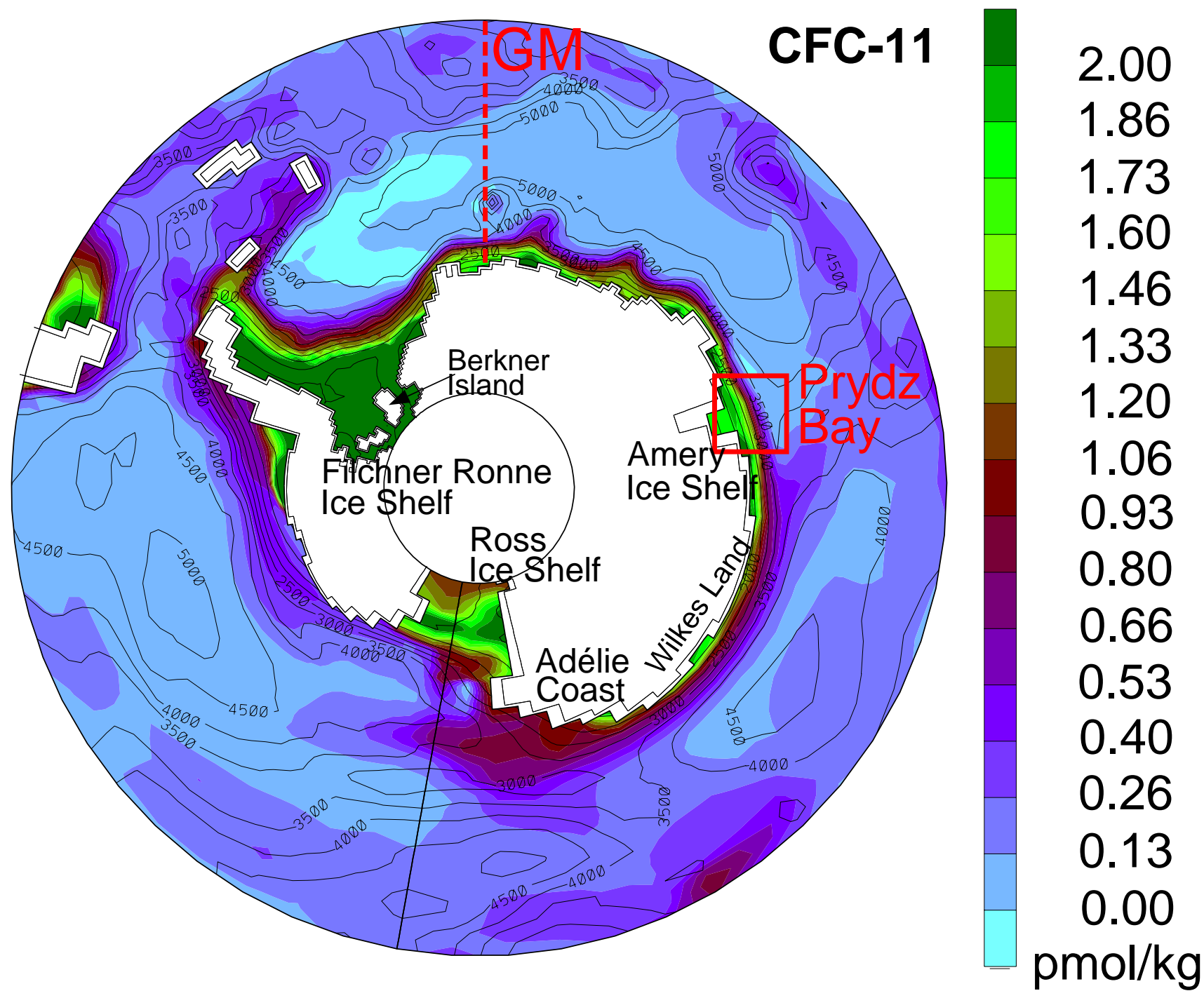


Figure 2

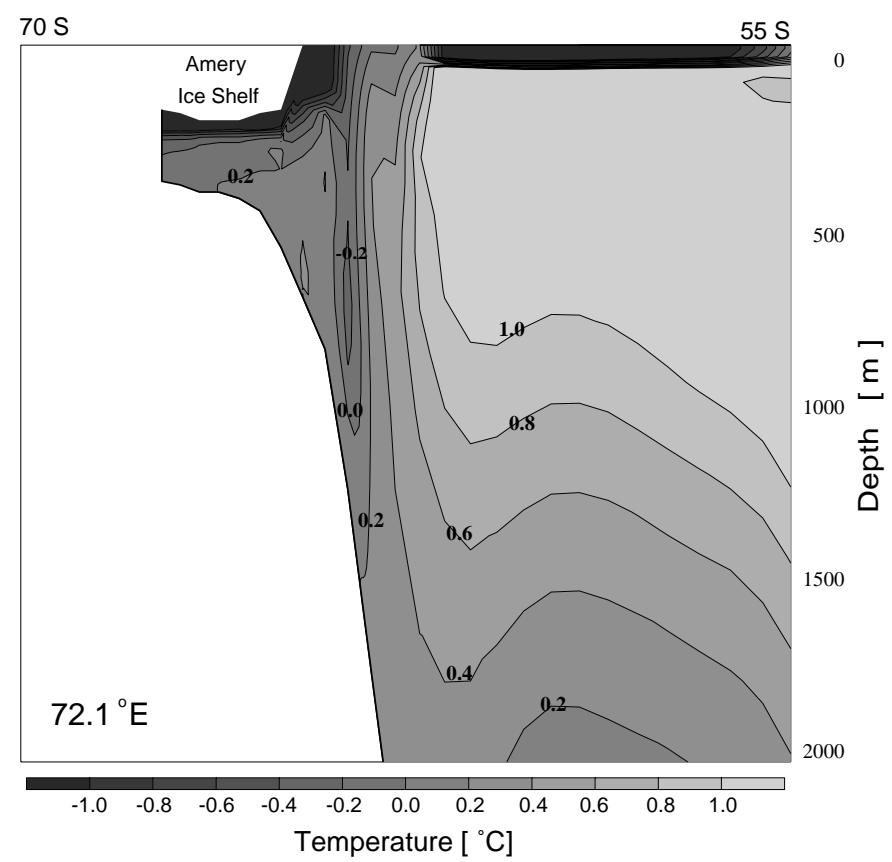


Figure 3

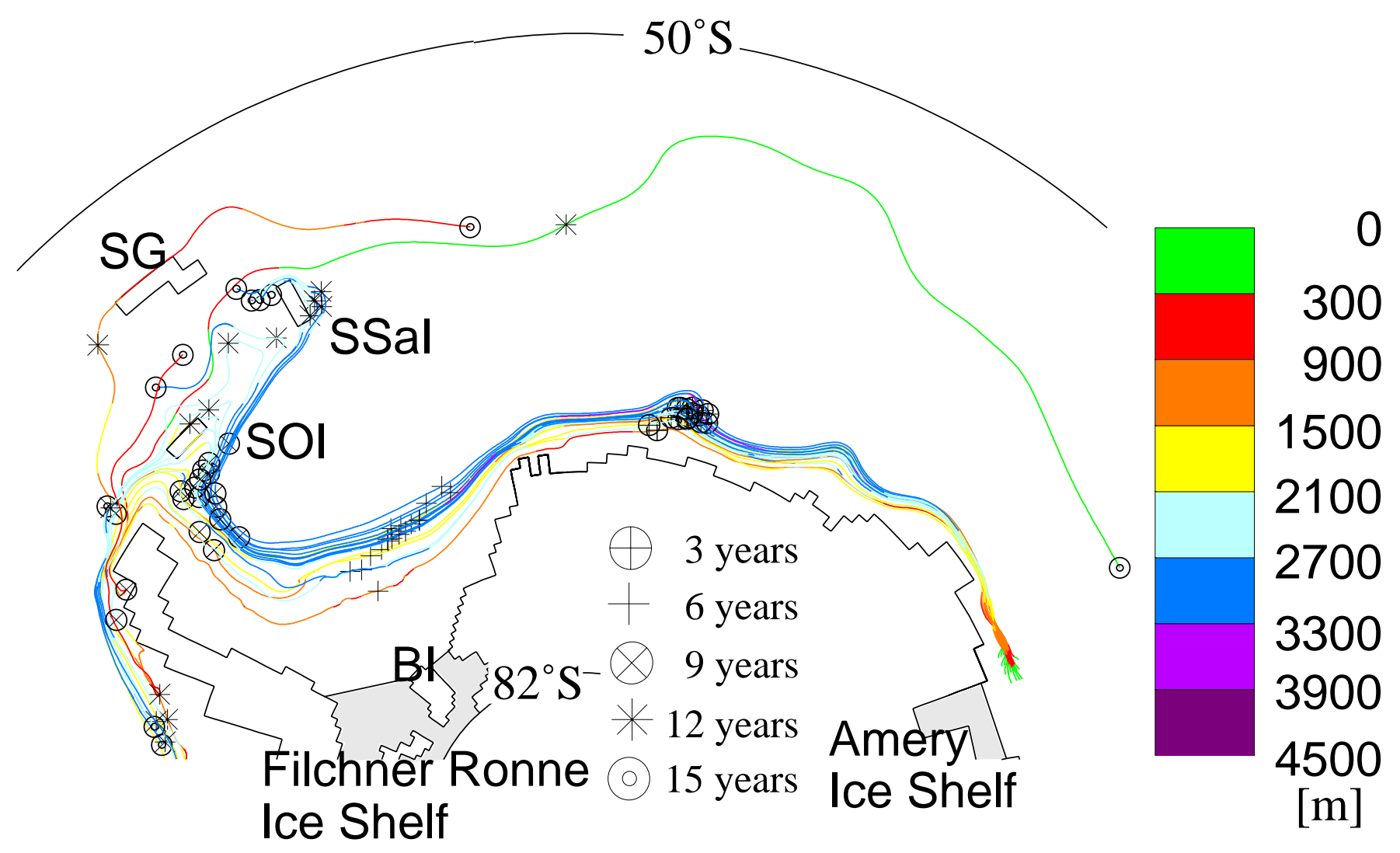


Figure 4

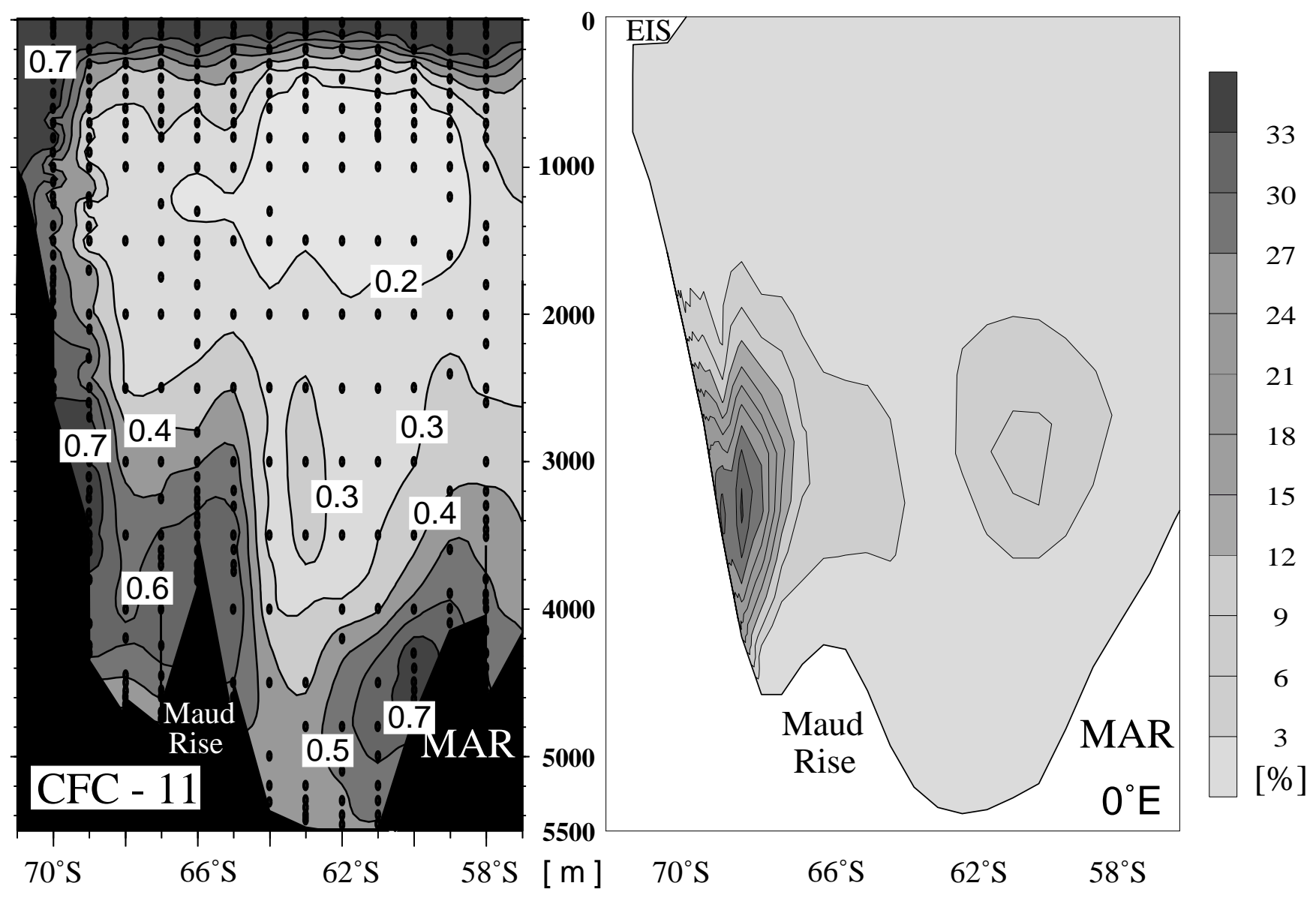




\section{Figure 5}
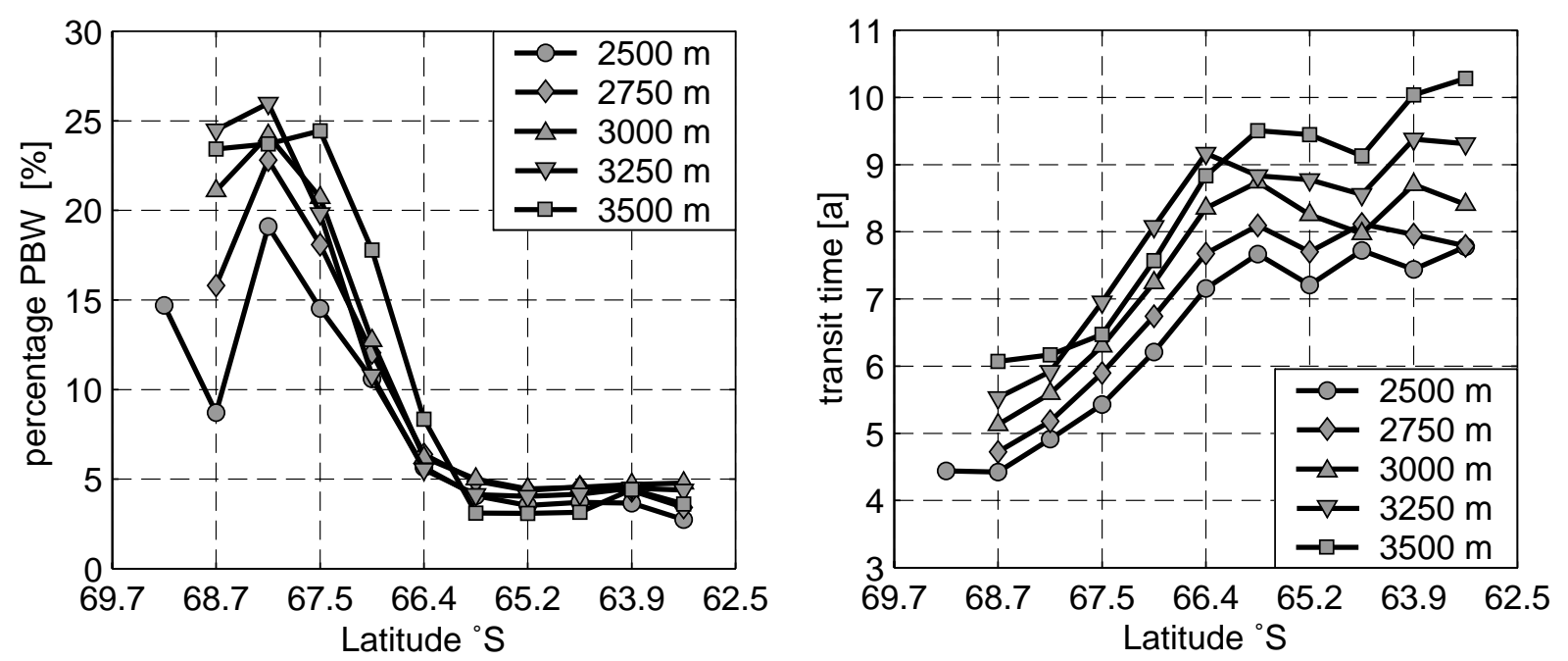

SCHODLOK ET AL.: ORIGIN OF WEDDELL SEA DEEP CFC-MAXIMUM

SCHODLOK ET AL.: ORIGIN OF WEDDELL SEA DEEP CFC-MAXIMUM

SCHODLOK ET AL.: ORIGIN OF WEDDELL SEA DEEP CFC-MAXIMUM

SCHODLOK ET AL.: ORIGIN OF WEDDELL SEA DEEP CFC-MAXIMUM

SCHODLOK ET AL.: ORIGIN OF WEDDELL SEA DEEP CFC-MAXIMUM

SCHODLOK ET AL.: ORIGIN OF WEDDELL SEA DEEP CFC-MAXIMUM

SCHODLOK ET AL.: ORIGIN OF WEDDELL SEA DEEP CFC-MAXIMUM

SCHODLOK ET AL.: ORIGIN OF WEDDELL SEA DEEP CFC-MAXIMUM

SCHODLOK ET AL.: ORIGIN OF WEDDELL SEA DEEP CFC-MAXIMUM

SCHODLOK ET AL:: ORIGIN OF WEDDELL SEA DEEP CFC-MAXIMUM

SCHODLOK ET AL.: ORIGIN OF WEDDELL SEA DEEP CFC-MAXIMUM

SCHODLOK ET AL.: ORIGIN OF WEDDELL SEA DEEP CFC-MAXIMUM

SCHODLOK ET AL.: ORIGIN OF WEDDELL SEA DEEP CFC-MAXIMUM

SCHODLOK ET AL.: ORIGIN OF WEDDELL SEA DEEP CFC-MAXIMUM 
SCHODLOK ET AL.: ORIGIN OF WEDDELL SEA DEEP CFC-MAXIMUM

SCHODLOK ET AL.: ORIGIN OF WEDDELL SEA DEEP CFC-MAXIMUM SCHODLOK ET AL.: ORIGIN OF WEDDELL SEA DEEP CFC-MAXIMUM SCHODLOK ET AL:: ORIGIN OF WEDDELL SEA DEEP CFC-MAXIMUM SCHODLOK ET AL.: ORIGIN OF WEDDELL SEA DEEP CFC-MAXIMUM SCHODLOK ET AL.: ORIGIN OF WEDDELL SEA DEEP CFC-MAXIMUM SCHODLOK ET AL.: ORIGIN OF WEDDELL SEA DEEP CFC-MAXIMUM SCHODLOK ET AL.: ORIGIN OF WEDDELL SEA DEEP CFC-MAXIMUM SCHODLOK ET AL.: ORIGIN OF WEDDELL SEA DEEP CFC-MAXIMUM SCHODLOK ET AL.: ORIGIN OF WEDDELL SEA DEEP CFC-MAXIMUM SCHODLOK ET AL.: ORIGIN OF WEDDELL SEA DEEP CFC-MAXIMUM SCHODLOK ET AL.: ORIGIN OF WEDDELL SEA DEEP CFC-MAXIMUM 